\section{ECONOMICS}

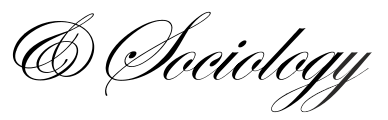

Swadźba, U., \& Horáková Hirschler, N. (2019). Value of work in the experience of the young generation of Visegrad countries. Economics and Sociology, 12(1), 177192. doi:10.14254/2071-789X.2019/12-1/10

\title{
VALUE OF WORK IN EXPERIENCE AND AWARENESS OF THE YOUNG GENERATION IN VISEGRAD COUNTRIES
}

\author{
Urszula Swadźba, \\ Silesian University \\ Katowice, Poland \\ E-mail: \\ urszula.swadzba@us.edu.pl
}

\section{Nicole Horáková Hirschler, University of Ostrava \\ Ostrava, Czech Republic \\ E-mail:nicole.horakova@osu.cr.}

Received: August, 2018

1st Revision: December, 2018

Accepted: February, 2019

DOI: $10.14254 / 2071-$

789X.2019/12-1/10

\begin{abstract}
The paper discusses the issues of experience and value of work, one of the elements of economic awareness of the young generation - students from the Visegrad countries. The paper presents the concept of work and its value according to Ronald Inglehart's value system. An analysis was carried out based on empirical research conducted in April-May 2015 and November 2016 in higher education institutions in the V4 countries (Poland: Katowice, Slovakia: Nitra, Czech Republic: Olomouc/Ostrava, Hungary: Gödöllö). ${ }^{1}$ In each country, the student groups were selected according to the auditor survey technique. The research covered Bachelor and Master students from four different types of studies: Economics, Management, Technical, Sciences, Medicine, Social Studies and Humanities. The resulting discussion concerns the work experience of the students in V4 countries and their statements concerning the value of work. A comparison will be made among the four national groups. In the "Discussion and Conclusion" part research questions are answered and a complex indicator of the value of work is constructed. The conclusion also contains a reference to Inglehart's theory and an answer concerning the question in which direction the values of work of the young generation in V4 countries are heading.
\end{abstract}

JEL Classification: A13, Z13 Keywords: values, work, young generation, Visegrad countries.

\section{Introduction}

Political transformations led to profound changes in the systems of values amongst adults and youth alike. Even though the pro-family and pro-professional orientation still exists amongst adults and youth, the market economy conditions have seen significant revaluations in the assessment of other goals and life aspirations as well as work-related aspects. Work has become a value and a source of other highly esteemed values (the income earned, satisfaction with achievements, intellectual development, social respect, and recognition, prestige). The young generation in Visegrad countries has no experiences of work in the period of real socialism. Their life experience revolves merely around the realities of the market economy.

\footnotetext{
${ }^{1}$ This paper is based on the materials gathered as part of the Visegrad Standard Grant: "The economic awareness of the young generation of Visegrad countries" no. 21420008. The participants, who are partners of the four universities, were: University of Silesia in Katowice, Palacky University in Olomouc, Constantine the Philosopher University in Nitra, Szent Istvan University in Godollo. In addition, research was also conducted by employees of the Department of Sociology of the Ostrava University.
} 
This generation has the chance to become fully involved in the economic, social and cultural processes of the Western world. And it is the first generation whose reality is fully based on the laws of capitalism, with all the opportunities and threats presented by this system, including those in the employment domain. Unemployment, difficulties in finding a good job, employment instability and "precariat" work are the daily reality on today's labour market. These factors influence the awareness of young people and their perception of work as such.

The objective of the paper is to diagnose one of the elements in the system of values, namely work, cherished by the young generation in Visegrad countries, as well as to answer the following questions:

1. To what extent does the young generation in V4 countries experience professional work during their studies? Is there a national specificity?

2. What value does the young generation ascribe to the acceptance of work statements? Does the experience of work affect the way it is valued and can national specificities be observed?

These research questions will be answered in the conclusion of this article. A complex indicator will also be presented, constructed through the aggregate indexation of the statements concerning the value of work

\section{Literature review}

The value of work, especially professional work, of the young generation from Visegrad countries, is going to be the subject matter of our analysis. The following analysis is part of a larger research project investigating economic awareness of young people in the V4 states (Swadźba, 2017, p. 869). One of the elements of economic awareness is work. Work in theoretical concepts is most frequently presented as a human activity that converts the external world. Sociological definitions of work point to the social aspects of work: values, attitudes, and structure of the group. An example of the classic sociological definition of work is the one formulated by Urszula Swadźba: "Work is a social activity, professional and nonprofessional, focused on meeting the needs of people. In the course of performing their work individuals coordinate their behavior and come together in cooperation. Through the process of the work, the structure of the group is created and there is a process of integration. In connection with its implementation, the group develops values and standards" (Swadźba, 2001, p. 22). Work, in sociological terms, is very closely related to the concept of professional work and still refers to it. Sociological studies on work often focus on its value (Hajdu and Sik, 2018; Sortheix et. al., 2019).

An important role in analysing the system of values, including the value of work, is the theory of Ronald Inglehart (Inglehart, 1977). The basis of Inglehart's theory of values was the "Theory on Needs" of Abraham Maslow. According to this theory, human needs are hierarchical. The most important arephysiological and safety needs. After addressing basic needs, an individual will strive for the implementation of other intangible needs. This means that with ongoing economic prosperity there is a transition from materialistic values (ensuring the safety and survival) to post-materialist values (emphasizing the need for self-expression and quality of life). For these two premises, it can be concluded that there are considerable differences between the value systems of the young and the older generations. Older people, who live with deficits, tend towards materialistic values. The younger generation, which has matured in terms of economic growth, the absence of wars and a universal offer of goods and services, would favour post-materialistic values.

Inglehart's concept carries much theoretical weight and explains the change of the contemporary value systems. It also underwent much criticism and additions to its concept (Flanagan, 1987; Fukuyama, 2000; Klages, 2001). One of them was developed in the Polish 
context (Ziółkowski, 2006). Marek Ziółkowski believes that Inglehart's thesis requires reinterpretation. In Inglehart's materialism/post-materialism scale, there are - as a matter of fact - two independent tendencies that can be described in a two-dimensional range of values (interests): one is related to existential values (e.g. work), the other - to cultural issues (religion, family) (Ziółkowski, 2006, pp. 147). The concept by R. Inglehart, supplemented with the remarks formulated by M. Ziółkowski, is very broad and contains an analysis of numerous values. The values analysed are autonomous, they can be isolated and concluded upon separately. This can be particularly true for work which is - according to Ziólkowski an existential value and its transformations exhibit their own specificity. Research on the changes in the value system has been carried out in Europe and also in V4 countries by numerous scientists (Inglehart et. al., 2004; Siemieńska, 2004; Kusy \& Zeman 2008; Halman et al., 2011; Mladek, 2012; Vlachová, 2013). Changes in the value system have an impact onto other systems important for society. One is e.g. the concept of work and its changing value which is also discussed by different authors (Mareš, 2004, Marody, 2012, Swadźba, 2012; Hajdu \& Sik, 2018; Horáková, 2018).

The younger generation, especially students, stands only at the beginning of their professional career. Their experiences are generally not significant and often related to seasonal work during the holidays or temporary work during the academic year. It is often socalled "precariat" work (Standing 2014; Standing 2015). The flexibility of working-time and the employment instability are becoming the main source of rationalisation and the growth of productivity in all the three dimensions of work, namely time, place and contract (Beck 2000; Beck 2002; Keller 2005; Keller 2010). An increasing number of employment relationships will be deregulated and concluded for a short period. A similar view is shared by Zygmunt Bauman who gives a dichotomous picture of the labour market. There will be individuals with permanent employment, while the rest of the employees will only be a reserve workforce ("routine employees"), that will change employers depending on the needs of both sides (Bauman, 2006; Bauman, 2009). There will be too little work for everyone and for those who will be employed work will be related to self-development and pleasure (Bauman, 2006, pp. 73-84). However, the remaining group will include individuals, especially young people, who will be employed for a definite period. This type of work is particularly addressed to students.

Student employment has a long-standing tradition (Jacob et al., 2018; Body et al., 2014). But it was not very popular in the period of real socialism dominated by full employment and full-time jobs. In the realities of the market economy, the spreading model of consumerist lifestyle, the growing unemployment and the flexible labour market, it was getting increasingly common for students to be the much-needed workforce (Bachmann and Boes, 2014; Baum and Ruhm; 2016). This situation motivates students to take up work during their studies. Working while studying is a hard task because students have to combine work with their university duties. Very often it can cause conflicts in the distribution of time, not taking part in classes and graduating from university later (Golden and Baffoe-Bonnie, 2014; Body et al., 2014). It also precludes developing other activities during studies (Bartolj and Polanec, 2018). However, there are also some positive sides: Professional work during the academic year or in the holiday period is supposed to bring not merely financial profits but also an opportunity to gain experience (Baert et al., 2016). Therefore, it is common for young people to become increasingly aware of the fact that professional work during their studies is the key to success. 


\section{Methodological approach}

The empirical analysis is based on the research conducted in April-May 2015 and November 2016, in four V4 countries - Katowice, Poland (University of Economics in Katowice, University of Silesia in Katowice and Silesian University of Technology), Olomouc and Ostrava, Czech Republic (Palacky University in Olomouc, University of Ostrava and Technical University of Ostrava), Nitra, Slovakia (Constantine the Philosopher University in Nitra and Slovak University of Agriculture in Nitra), Gödöllö, Hungary (Szent Istvan University in Gödöllö).

Firstly, a common questionnaire survey was prepared in English and then translated into the national languages. The questionnaire included 37 extended questions (all elements of economic awareness) and 10 questions according to socio-demographic characteristics.

In every country groups of students were selected to take part in the research using an auditor survey technique. The research was based on Bachelor and Master level students from four different types of studies: economics and management, technical, sciences or medical, social studies and humanities. The surveys were carried out by the employees participating in the grant. Additionally, in November 2016, 90 surveys were carried out by the employees of the Department of Sociology, University of Ostrava. In Poland and in the Czech Republic were both conducted 400 surveys, in Slovakia 387 and in Hungary 368, jointly 1555 surveys from these four V4 countries. The collected empirical material was encoded and statistically analysed using the SPSS program. Four statistical bases have emerged for further analysis: a Polish, a Czech, a Slovakian and a Hungarian one.

Our article will only focus on answers according to questions about work. The basis for the analysis are two main questions:

The first question: "Despite your studies, do you work or have you been working in the past year during the academic year? $(\%)$. The students were requested to choose between four possibilities: "Yes, full-time", "Yes, part-time", "Yes, but only occasionally", "No". In the second question, the respondents were confronted with five statements:

S1: Work is necessary to ensure that a person can fully develop their talents;

S2: People should work even for a pittance;

S3: No one should be forced to work if he does not want to;

S4: Work should be put in the first place, even if this means sacrificing more time;

S5: It is good to work in the same company for a long time.

The students had five possible answers to choose from: "definitely yes", "rather yes", "rather not", "definitely not" and "hard to say".

The results are presented in tables (in percentage data), graphs and correlations with Chi-square and Cramer's V in the text below.

\section{Conducting research and results}

The research results contain the analysis of the questions about taking up work during the academic year. Next, an analysis of the five statements concerning work is provided. Four of these statements were also part of the European Values Studies (EVS) and they can be seen as indicators in showing the value of work. The analysis involves a comparison of the four national groups and discusses their specificity.

The respondents in Poland included $45 \%$ of men and $55 \%$ of women, in the Czech Republic $-31,5 \%$ of men and $68,5 \%$ of women, in Slovakia $-31,8 \%$ of men and $67,2 \%$ of women and in Hungary $-41,0 \%$ of men and 59,0 of women. The age of the students taking part in the survey is precisely defined. It is usually the 19 to 25 age bracket as the majority of young people take up their studies at that time. 
Table 1. Age structure of the interviewed students (\%)

\begin{tabular}{lcccc}
\hline \multicolumn{1}{c}{ Age } & Poles & Czechs & Slovaks & Hungarians \\
& $\mathrm{N}=400$ & $\mathrm{~N}=400$ & $\mathrm{~N}=387$ & $\mathrm{~N}=369$ \\
\hline $18-19$ & 0,0 & 0,8 & 1,3 & 0,0 \\
\hline 20 & 0,0 & 1,3 & 17,1 & 0,0 \\
\hline 21 & 0,3 & 9,3 & 28,4 & 21,8 \\
\hline 22 & 1,0 & 15,3 & 16,3 & 20,0 \\
\hline 23 & 59,3 & 19,3 & 15,5 & 16,9 \\
\hline 24 & 23,5 & 20,8 & 7,8 & 16,1 \\
\hline 25 & 7,0 & 9,5 & 4,4 & 9,3 \\
\hline Over 25 years old & 8,9 & 4,2 & 3,5 & 15,7 \\
\hline No response & 0,0 & 19,5 & 5,7 & 0,0 \\
\hline Total & 100,0 & 100,0 & 100,0 & 100,0 \\
\hline
\end{tabular}

Source: own data

The age of the students in the individual national groups differs slightly: The age of Polish students centers around the 23 to 24 age bracket $(82,3 \%)$. Czech students are between 22 to 24 years old $(55,4 \%)$. Slovak and Hungarian students have a slightly different age structure. Slovakian students are the youngest among the examined ones $(46,8 \%$ in the $18-21$ age bracket). Hungarian students are slightly older than the others and especially in comparison with Slovak students - 21,8\% of them are at the age of 21 and $25 \%-25$ and over 25 years old. Such a diversity of age can have an influence on students' knowledge about the economic phenomena, their life experience and the interest of the examined problems.

\subsection{Undertaking professional work by students of V4 countries}

Our first question deals with the work undertaken by the students during the academic year. The labour market offers a series of jobs that make it possible to reconcile work and study. Some companies, especially those rendering services, create workplaces particular for students. However, it should be emphasised that such an activity is difficult because students then have to combine work and study-related duties. It can be a full-time, part-time or casual job, which helps students to patch up their budgets and, at the same time, gain valuable experience (Kowalczuk, 2014).

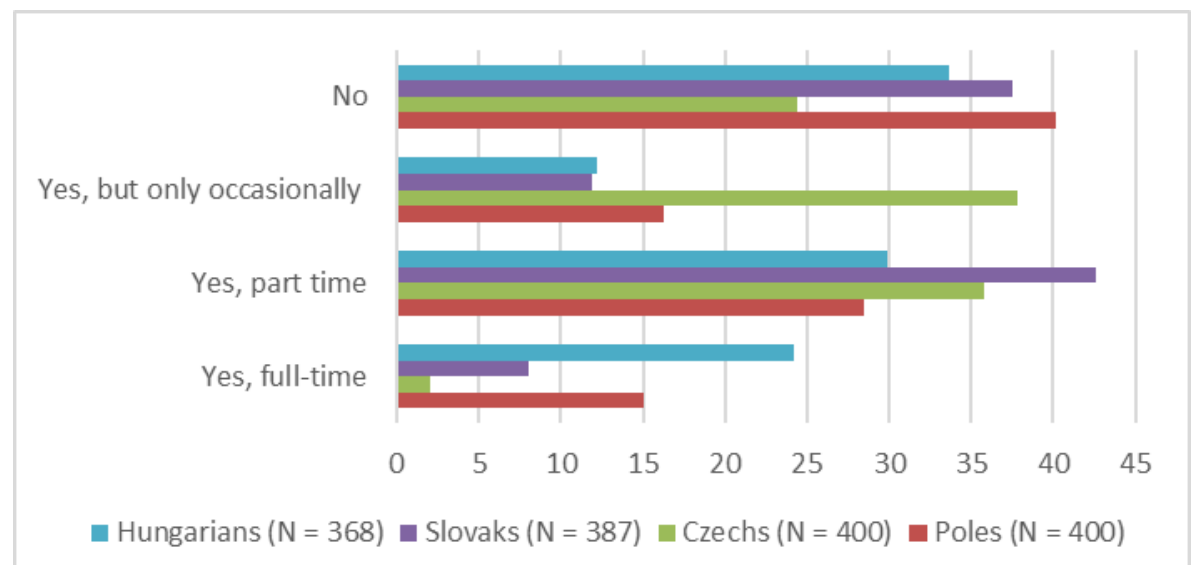

Figure 1. Despite your studies, do you work or have you been working in the past year during the academic year? $(\%)$

Source: own data 
The analysis of the above data indicates certain differences in experiencing work by the students of V4 countries. More than $40 \%$ of the Polish students work during the academic year, which is a high percentage. However, considerably fewer of them have a full-time employment $(15 \%)$. These are mostly part-time or distance students visiting the university only at the weekend. Full-time students find it very hard to combine their studies with this type of employment. Nearly $1 / 3$ of the students work part-time. This is certainly the optimal solution for those who reconcile work and study. It is not so time-consuming and makes it possible for students to fulfil their duties at the university while gaining professional experience. Such work, however, is of a precariat nature (Hipsz 2014; Kalka 2016). Analysing the experience of work by the Polish students, one can distinguish two categories: On the one hand, a considerable part of the students undertake employment, but on the other hand, almost the same percentage of them do not work during the academic year at all. This is the highest percentage amongst the students of V4 countries.

In the other V4 countries, the percentage of students who do not take up any jobs is lower (Swadźba, 2018). The greatest experience with gainful employment is possessed by the Hungarian students. Nearly $1 / 4$ of them work full-time during the academic year, and nearly 30 $\%$ part-time. Great experience with work can be also observed amongst the Slovakian students, because half of them are employed part-time during the academic year. The Czech students, in turn, have the least experience with gainful full-time employment. Most commonly, they undertake part-time or casual work, whereas only $1 / 4$ of them do not undertake any employment at all (the lowest percentage amongst the V4 students).

\subsection{Statements concerning work}

Having analysed and characterised the experience of work by students, the paper intends to present an analysis of statements concerning work. These statements indicate the value of work. The respondents were confronted with the following statements, whereby each of the statements should be treated as a separate question: S1: Work is necessary to ensure that a person can fully develop their talents; S2: People should work even for a pittance; S3: No one should be forced to work if he does not want to; S4: Work should be put in the first place, even if this means sacrificing more time; S5: It is good to work in the same company for a long time.

We provided an analysis of the statements in the frame of a comparative analysis of the respective national groups, their similarities and differences. The first two statements, as well as the fourth statement, indicate the value of work. The third statement gives information about the preference for other values besides work, while the fifth refers to attitudes according to current developments on the labour market.

Despite certain differences between the particular national groups of students, the analysis of the research results makes it possible to distinguish at least three levels of acceptance for the above-mentioned statements. The first level concerns statement 1 and statement 5. Here we see a high level of acceptance for these statements (in total: S1: 75,3\%, S5: 62,8\%); the other level encompasses the statements number 2 and 3 (in total: S2: 39,6\%, S3: $38,8 \%$ ), the lowest level of acceptance has statement number 4 (S4: 29,6\%). The detailed analysis of the statements, according to the particular national groups, is showed below. 


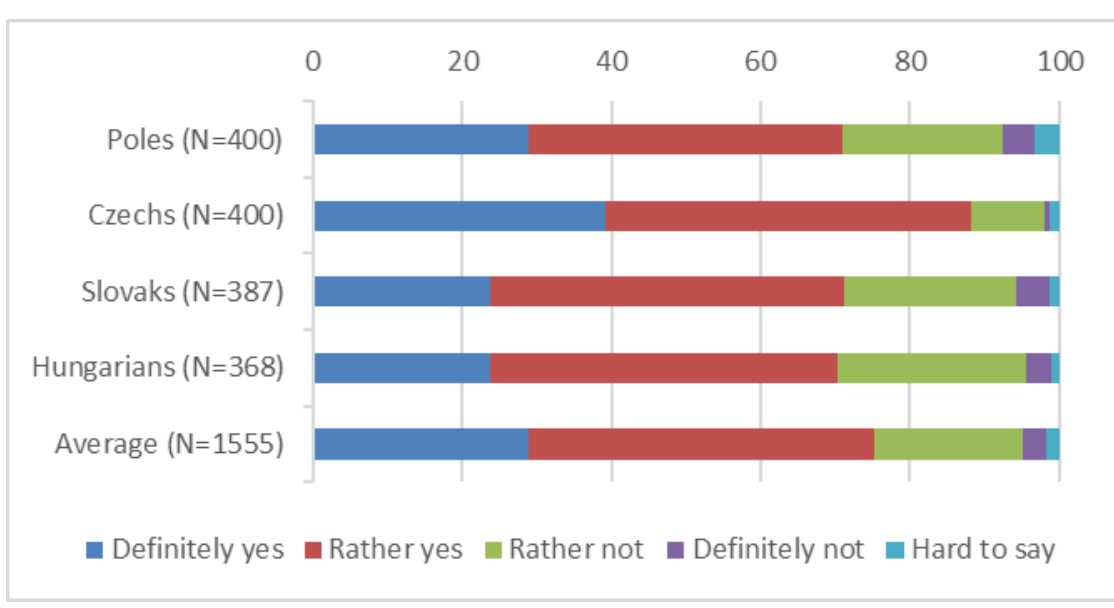

Figure 2 Statement 1 . Work is necessary to ensure that a person can fully develop their talents $(\%)$

Source: own data

The first statement is particularly important because it demonstrates the perception of work as the source for the development of talents: "Work is necessary to ensure that a person can fully develop their talents". This statement is definitely accepted by $29.0 \%$ of the Polish students, $39.3 \%$ of the Czech students, $23.8 \%$ of the Slovakian students and $23.9 \%$ of the Hungarian students. If we also consider the answer "rather yes", then the Polish, the Slovakian and the Hungarian students accept the statement at the level of approximately 70 $\%$, while the Czech students - at the level of $80 \%$. This would mean that they perceive the value of work in the development of their talents in a more decisive manner. Only a low percentage of students definitely fail to see any prospects for developing talents through work (approx. $3-4 \%$ ), with approximately $20-25 \%$ of them rather not perceiving such prospects. It can be assumed that other activities, such as e.g. leisure, for students is another important source that helps them to develop their talents. Interestingly, in this regard, it is again the Czech students that deviate from these tendencies, with only $10 \%$ of them giving such responses.

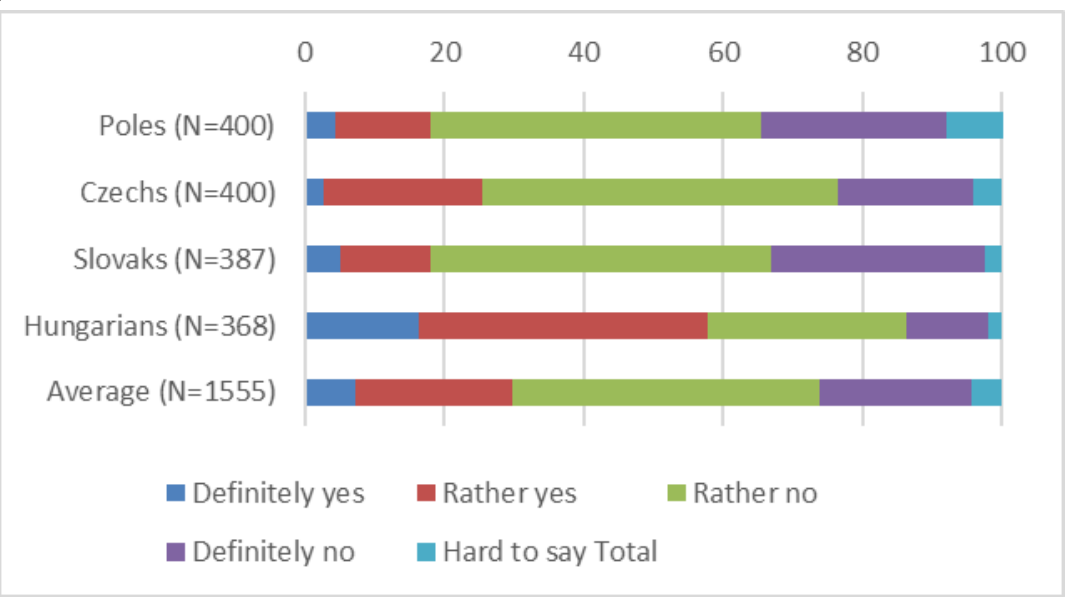

Figure 3 Statement 4 . Work should be put in the first place, even if this means sacrificing more time $(\%)$

Source: own data

Statement 4 verifies the cohesion of the previous views as it indicates the acceptance of work-related behaviours: "Work should be put in the first place, even if this means sacrificing more time". Such a situation is definitely accepted by a low percentage of Polish, 
Czech and Slovakian students (from 2.8 to $5.2 \%$ ), with the Hungarian students being an exception in this respect (16.3\% of them accepted statement 4). Moreover, if we additionally consider the answer "rather yes", then the acceptance rate amongst the Polish, the Czech and the Slovakian students ranges from $18 \%$ to $25.6 \%$, while in the case of the Hungarian students - amounts to over $50 \%(57.3 \%)$.

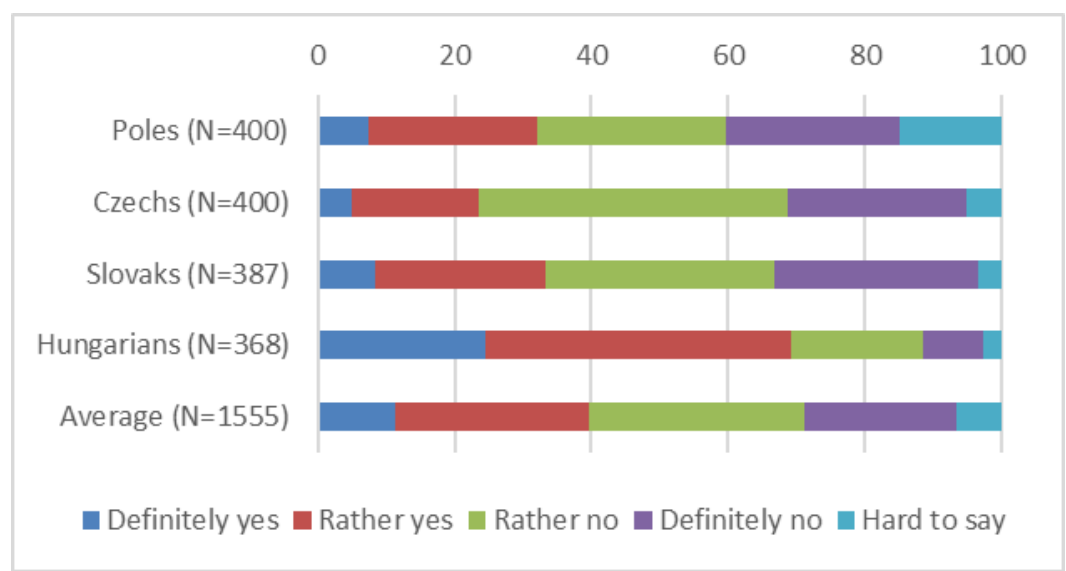

Figure 4 Statement 2. People should work even for a pittance Source: own data

A complementary statement to all the previous ones is the S2, reading: "People should work even for a pittance". The students rather do not accept such a situation and the vast majority of them reject this statement. However, there is a difference between the views held by the students of the following three countries (Poland, the Czech Republic, and Slovakia) and the views of the Hungarian students: The students of the three countries mentioned above accept this statement to a less definite degree (5.0\% Czechs, $6.5 \%$ Poles, $8.5 \%$ Slovaks) than the Hungarian students $(24.5 \%)$. A relatively large proportion of the Polish, the Czech, and the Slovakian students definitely do not agree with this statement (approx. 25 - $30 \%$ ), while such an opinion is expressed by merely $8.7 \%$ of the Hungarian students.

The students' views are therefore rather consistent: The vast majority of the students from the three countries referred to above, namely Poland, the Czech Republic, and Slovakia, accept the view that work is necessary for an individual to fully develop his talents. On the other hand, however, they are neither willing to devote themselves to this work nor eager to work for a pittance. This is particularly true of the Czech students, where this discrepancy is the largest. It is only the Hungarian students that would also support such views in practice.

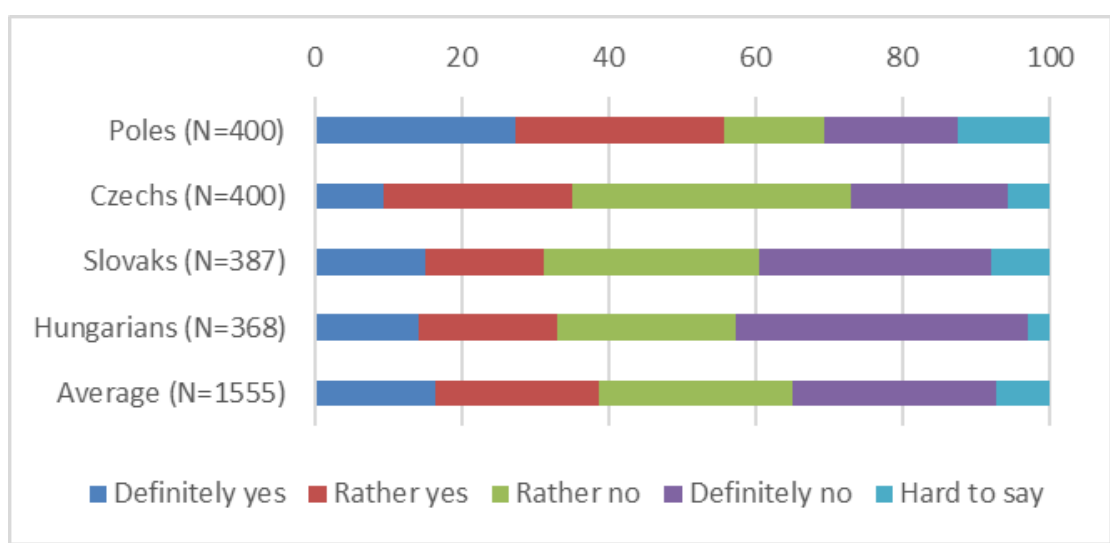

Figure 5 Statement 3 . No one should be forced to work if he does not want to. (\%) Source: own data 
A relatively low level of acceptance has been given to statement 3, namely: "No one should be forced to work if he does not want to". However, there are certain national differences in terms of the acceptance level. A small proportion of the Slovakian, the Czech and the Hungarian students "definitely accept" this statement (Czechs $-9.5 \%$, Slovaks -15.0 $\%$, Hungarians $-14.1 \%$ ). Including the answer "rather yes", this statement is accepted by approximately $1 / 3$ of the students. A surprising view is expressed by the Polish students. The statement was indicated by more than $50 \%$ of the respondents ("definitely yes" and "rather yes" $-55.8 \%$ ), and not accepted by about $30 \%$ of them ("rather not" and "definitely not" $31.8 \%$ ). More than half of the Polish students, therefore, believe that people who are not willing to work should not be forced to. Such responses can be explained by the fact that young people who are supported by parents show a lower level of acceptance for this statement. They do not have to worry about earning a living and claim that a young individual is not always obliged to work. The question concerning professional activity revealed that the Polish students had the highest proportion of economically inactive individuals, thereby explaining the higher percentage of such responses.

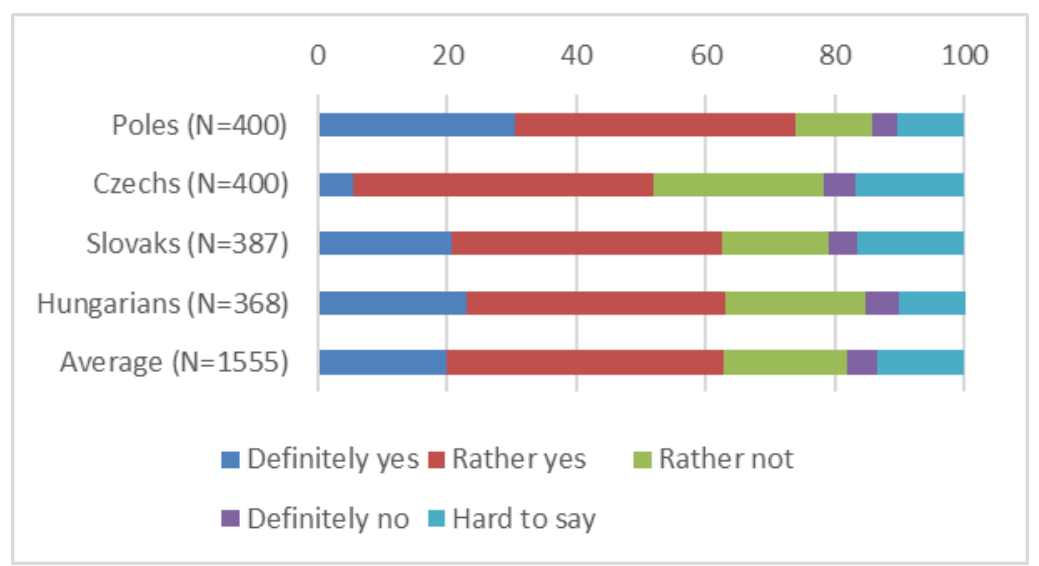

Figure 6 Statement 5. It is good to work in the same company for a long time (\%) Source: own data

The Polish students also exhibit a distinct approach to responding to the last statement (5), namely "It is good to work in the same company for a long time". In the period of real socialism, working in one company/institution throughout one's professional career was standard. Currently, this situation is not too common, especially amongst the young. The labour market has changed and new companies emerged, meeting the demand of the economy. Young people are aware of this phenomenon and adapt themselves to the existing reality. On the other hand, employment in one company/institution ensures professional and financial stability. The students must have borne this in mind when they expressed their view on the statement in question. Most of the students had a positive view of this statement (acceptance: "definitely yes" and "rather yes"). However, there are certain national differences: Approximately $1 / 5$ of the Slovakian and the Hungarian students decisively accepted this statement. However, it was confirmed by only $5.5 \%$ of the Czech students and by over $30 \%$ of the Polish students. The answers "rather yes" are at the same level in all national groups (approximately $40-45 \%$ ). The answer "rather not" was given more or less by the same percentage of respondents $(4.0-5.2 \%)$. What can be the reason for such a big discrepancy between the responses of the Polish students (and, to a slightly smaller degree, also their Slovakian and Hungarian counterparts) and the Czech students? The answer lies in the differences present in the corresponding labour markets. The unemployment rate in the Czech Republic has compared to the other V4 countries retained its low level for years, and hence it is not difficult to find a job. Therefore, the students show no need to feel attached to a 
single workplace and they are not afraid of changes in order to find the most suitable job for them. Are there any relationships in the students' responses that result not only from their nationality? Does the performance of work affect the way it is valued? The analysis of the responses suggests that there are no substantial differences in the value of work depending on the performance of work by the students. In the vast majority, the statements in correlation with the performance of work are not statistically significant as Table 2 shows.

Table 2. Statements in correlation with the performance of work (chi-squared test)

\begin{tabular}{lcccc}
\hline \multicolumn{1}{c}{ Statements } & Poles & Czechs & Slovaks \\
& $\mathrm{N}=400$ & $\mathrm{~N}=400$ & $\mathrm{~N}=387$ & $\begin{array}{c}\text { Hungarians } \\
\mathrm{N}=369\end{array}$ \\
\hline & \multicolumn{2}{c}{ the level of $\mathrm{p}$} \\
\hline S. 1. & 0.567 & 0.11 & 0.493 & 0.064 \\
\hline S. 2. & 0.345 & 0.303 & 0.042 & 0.562 \\
\hline S. 3. & 0.467 & 0.00 & 0.370 & 0.919 \\
\hline S. 4. & 0.624 & 0.753 & 0.310 & 0.430 \\
\hline S. 5. & 0.396 & 0.006 & 0.020 & 0.255 \\
\hline
\end{tabular}

Source: own data

Only in the case of the Czech students, statement S3 demonstrated a statistical relationship, while statement S5 is close to a statistical relationship (S3 the chi-squared test at the level of $p=0.00$, Cramer's V 0.200, S5 the chi-squared test shows no significance: at the level of $p=0.006$, Cramer's V 0.145). In the case of other statements, there are certain percentage differences.

Statement S1, namely: "Work is necessary to ensure that a person can fully develop their talents" is supported more decisively by the Polish students who do not work. The Hungarian and the Slovakian students accept this statement in the same level (approx. $22 \%$ ) irrespective of whether they work full-time or have no job. Only working students accept this statement in a vast majority (84.6\%) compared to non-working individuals $(45.5 \%)$. This means that the performance of work does not affect the way it is perceived as the source for the development of talents. The reason for this may be that students often hold jobs which do not require high qualifications and which are not compatible with their education. This makes it harder for them to discern their personal development and creativity when they perform their duties.

Similarly, a slightly stronger support is provided by the non-working Polish students for S2: "People should work even for a pittance". The working Polish students are less eager to support a situation in which they have to work for a paltry paycheck. A similarly low level of acceptance is demonstrated by the Czech and the Slovakian students, irrespective of whether they performed any professional work. There is also no relationship amongst the responses of the Hungarian students. The working and non-working individuals decisively accepted this statement at the level of $22 \%$.

Statement 3 ("No one should be forced to work if he does not want to") is accepted very reluctantly by the students, irrespective of whether they work or not. Interestingly, amongst the Polish students we find the highest percentage of those who agree with this statement (meaning that they do not accept any compulsion to work), female respondents are more common to decline it. The Czech students who work full-time are more likely to agree with this statement than the non-working individuals (working - $15.4 \%$, non-working $4.4 \%)$.

Statement S4, namely: "Work should be put in the first place, even if this means sacrificing more time" is slightly more often supported by the Polish, the Czech and the Hungarian students who have jobs. Perhaps, it is the effect of the necessity they face. Holding 
a full-time job, they are more likely to experience a situation, due to circumstances beyond their control, in which they have to go to work.

The last statement that does not directly concern the value of work, yet probes the students' expectations towards their future work, reads as follows: "It is good to work in the same company for a long time". A large percentage of both categories of the Polish, the Slovakian and the Hungarian students - i.e. working and non-working individuals, agree with statement S5, which is certainly an appreciation of the professional stability offered. The percentage of Czech students in full-time employment who resolutely accept S5 is higher $(23.1 \%)$ than that of their non-working counterparts $(8.1 \%)$.

Generally speaking, the analysis of the statements concerning the value of work in correlation with the performance of work showed no decisive influence of such statements on the value of and the attitude to work. It is only in the case of the Czech students that full-time employment affects the manner in which work is perceived and valued.

\section{Discussion and Conclusion}

Theoretical part of this paper explains that the transitional crisis is influenced by different institutional, economic, political, cultural, and the following factors: conflicts of formal and alternative institutions, global processes, liberalization of economy, domination of politics, etc. Characteristically, they had a multiple impact through several independent variables which we have analyzed in three countries in transition (Montenegro, Serbia, and Bosnia and Herzegovina). During the socialist period, these countries had centrally-planned economies, limited economic growth, and spiral reproduction of the crisis. However, they are a typical example of the general situation in the Eastern Europe. Therefore, the results of this research are expected to contribute to the understanding the transitional crisis in the most Eastern European countries. Apart from some positive processes and improvements (in business environment, tourism, liberalization, civil society, civil and political rights, democracy, freedom of the media, the development of a knowledge society, environment for investments, etc.) the observed countries experienced the intensification of the social, political and economic crisis for the last 25 years. Conducted Empirical research has verified it. A number of negative factors provoked the transitional crisis. The most important of them (from my perspective) are selectively identified and explored in this research.

The aim of our research was to diagnose one of the elements of the value scale - the value of work - and to find an answer to two research questions. The research showed that a significant proportion of students takes up professional work during their studies and has so the possibility to get acquainted to different aspects of it. The young generation of V4 countries experiences professional work to a significant extent. Therefore the first research question can be answered affirmatively. Most of the students who work during studies handle a different amount of time. These phenomena have already been described by other researchers (Manutti et al., 2018; Zupan et al., 2015; Novak \& Znidarsic, 2018). There were differences in taking up work between the students from different countries. This resulted mostly from the access to the labour market as well as from the age of students and their study degree. For example, Hungarian students who were older and studied at Master or PhD level were definitely more likely to take up a full-time job. Polish students also, slightly older, work more often full-time rather than younger Slovak and Czech students. The age and degree of study, which is connected with age were a decisive factor for working full-time. Working while studying mostly have positive aspects because it allows to get experience that can be helpful in further professional life (Bachmann \& Boes, 2014; Baum \& Ruhm, 2016; Swadźba 2016; Novak \& Znidarsic, 2018; Manutti et al., 2018). We should also point out the negative 
side of working while studying, which is negligence of student's duties (Swadźba, 2016; Bartolj \& Polanec, 2018).

The next research question concerned the acceptance of the value of work and the impact of working on the perception of its value (analysis of the five statements). To conclude the analyses of the work-related statements, a summary will be presented for the first four statements which indicate the value of and the attitude to work (figure 7). The changing value of work is a complex indicator, constructed through aggregate indexation of the first four statements concerning the value of work, as discussed in the paper (when constructing the indices, the answer "hard to say" was omitted). After indexation, a 13-degree scale was created and categorized into three parts corresponding to the positive, neutral and negative value of work.

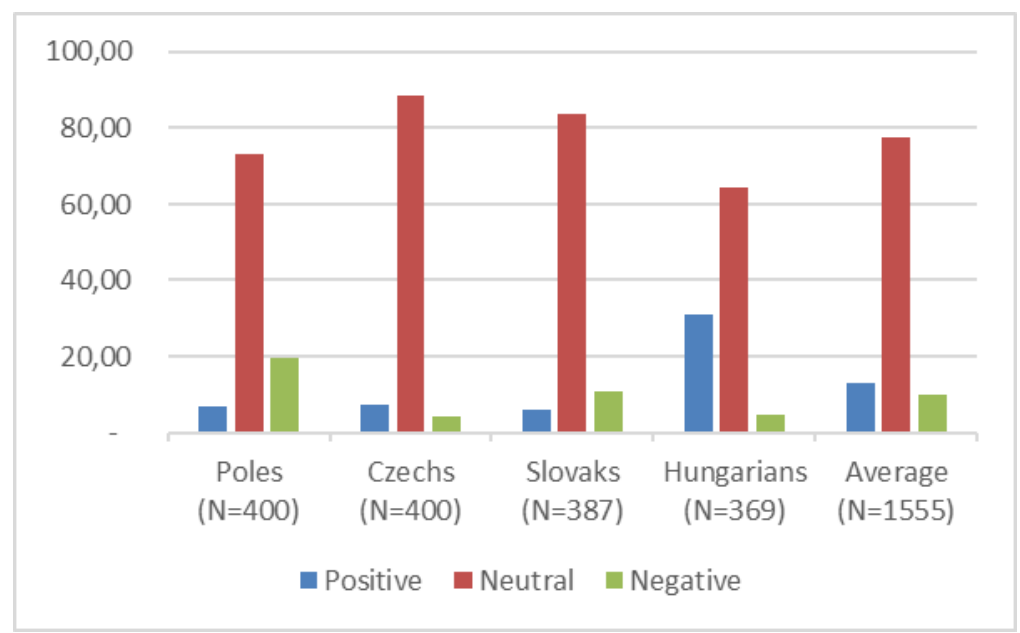

Figure 7. Total Value of Work (\%)

Source: own data

The analysis suggests that the majority of students from V4 countries show a neutral attitude to the value of work. It means that they place work as an essential value in their life, but it is not the most important value for them. Such dependences are also presented by the research of other researchers which were conducted in several European countries (Manutti et al., 2018; Hajdu \& Sik, 2018; Sortheix et al., 2019). Generally, despite perceiving the value of work and the opportunities for developing their talents through it, students do not want to work their whole life and do not consider it as priority number one. This implies that work is indeed important, but there are other activities which give them the possibility to develop one's talents. The issue at hand is probably the personal development at leisure, but also the professional development during foreign trips, training sessions and courses. There are differences in the acceptance of the value of work between students from different countries. Research results indicate that:

1. The choices made by the Polish students are the most surprising. Even though the positive value of work may be compared to the choices made by the Czech students, nearly $20 \%$ of the Polish students demonstrate a negative value of work and a negative attitude to it. This particularly concerns the support for the following statement: "No one should be forced to work if he does not want to".

2. Amongst the Czech students, more than $7 \%$ find work to be a positive value. They have the highest percentage of individuals who rate work in a neutral manner as well as a relatively low proportion of individuals with a negative attitude to work. They demonstrated the highest acceptance for $\mathrm{S} 1$ which indicates a positive rating of work and the lowest acceptance for the following statement: "People should work even for a pittance". 
3. The Slovakian students demonstrate to a great extent a neutral attitude to work, constituting over $80 \%$ of the respondents. The lowest percentage of the respondents $(5.8 \%)$ has a positive attitude to work and appreciate its value. A negative attitude towards the value of work is held by more than $10 \%$ of the students. This percentage is slightly higher than in the case of the Czech and the Hungarian students, and lower than for the Polish students. Such a result was influenced, amongst others, by the highest percentage of a decisive lack of acceptance for the following statement: "Work should be put in the first place, even if this means sacrificing more time".

4. The Hungarian students assign the highest value to work. Amongst them, the greatest number of individuals have a positive attitude to work. This is as many as $1 / 3$ of the respondents. Almost all the statements are "definitely accepted" by a considerable proportion of the Hungarian students, and very few of them have a definitely negative opinion on the issues. Neutral attitude is demonstrated by only $60 \%$ of the students, with a low percentage having a negative attitude.

It should be asked what are the differences in evaluating the value of work resulting from. Hungarians students present a particularly positive value of work. In our opinion, this results from age, work experience and the type (nature) of professional work. The Hungarians are slighlty older and work more often full-time. It is more often work, which is compatible with their qualifications (management). A significant number of students live in Budapest, where it is easier to get this kind of work. Slovak students are younger and more often do work which is incompatible with their qualifications (Swadźba, 2018).

Responding to the research question if working influences its evaluation should be answered negatively. Working is not a depending factor. However, as research shows, the value of work is positively influenced by age, working full-time, having a job which can be presumed to meet the needs of the employee-student. The analysis of the collected materials, which was shown in a different publication, also indicates that there is a connection between the positive evaluation of work with having work that is compatible with one's qualifications. (Swadźba, 2016).

In conclusion, the problem contained in the theoretical part should be raised - the reference of research results to Inglehart's theory. Research of other authors show that the value of work at a young age is not high, it increases in middle age and declines in retirement age (Hajdu and Sik, 2018). The examined group of students are at the beginning of their professional career and they will have opportunities to experience the value of work. Obviously, a lot depends on objective factors, especially from the situation on the labour market and individual factors which increases or decreases the motivation for working (Sortheix et. al, 2019). Referring to the theory of Ronald Inglehart and its supplementation by Marek Ziółkowski, one can conclude that the students of V4 countries are inclined towards materialistic values as far as work is concerned. The research on the value of family and religion demonstrate that the Czech society, in particular, is driven by post-modernist and liberal values (Swadźba, 2013). Despite the generally common feature amongst the students surveyed concerning the value of work. However, they make it possible to draw conclusions about the experience of work by students and the value they ascribe to work. The analysis of the work values revealed that the young generation attaches great importance to work and understand that it is an essential part of their lives. They are dominated by materialistic values, yet becoming increasingly aware of post-materialistic values as well. 


\section{Acknowledgement}

The authors are thankful to the Visegrad Standard Grant: "The economic awareness of the young generation of Visegrad countries" no. 21420008 for financial support to carry out this research.

This paper has been financially supported by the University of Ostrava, Institutional Development Project (IRP) No. 201819 Social and Cultural Mechanisms of In- and Exclusion: a Comparative Perspective.

The authors are also thankful to the Faculty of Social Sciences, University of Silesia for the financial support.

\section{References}

Bachmann, A., \& Boes, S. (2014). Private transfers and college students' decision to work. Economics of Education Review, 42, 34-42.

Bartolj, T., \& Polanec, S. (2018). Does work harm academic performance of students? Evidence using propensity score matching. Research in Higher Education, 59(4), 401429.

Baert, S., Rotsaert, O., Verhaest, D., \& Omey, E. (2016). Student employment and later labour market success: No evidence for higher employment chances. Kyklos, 69(3), 401-425.

Baum, C. L., \& Ruhm, C. J. (2016). The changing benefits of early work experience. Southern Economic Journal, 83(2), 343-363.

Bauman, Z. (2006). Praca, konsumpcjonizm i nowi ubodzy. Kraków: Wydawnictwo WAM.

Beck, U. (2000). A global prospect: Beyond the work society. Global Focus, 12(1), 79-88.

Body, K. M. D., Bonnal, L., \& Giret, J. F. (2014). Does student employment really impact academic achievement? The case of France. Applied Economics, 46(25), 3061-3073.

Flanagan, S.C. (1987). Controversy. Values in Industrial Societies. The American Political Science Review, 4, 1289-1303.

Fukuyama, F. (2000). Wielki wstrzas. Natura ludzka a odbudowa porzadku społecznego, Warszawa: Wydawnictwo „Politeja”.

Golden, L., \& Batfoe-Bonnie, J. (2011). Work-study Conflict or Facilitation? Time Use Tradeoffs among Employed Students. Young people and work, 72, 121-141.

Hajdu, G., \& Sik, E. (2018). Age, Period, and Cohort Differences in Work Centrality and Work Values. Societies, 8(1), 6-33.

Halman, L., Sieben, I., \& van Zundert M. (2011). Atlas of European Values: Trends and Traditions at the Turn of the Century. Leiden, the Nederlands: Brill.

Horáková, N., \& Jalůvková, M. (2018). System of Value and Economics in Life. in: U. Swadźba (Ed.) The economic awareness of the young generation of Visegrad countries. A comparative analysis. Katowice: Wydawnictwo Uniwesytetu Śląskiego, 42-73.

Inglehart, R. et all. (Eds.) (2004). Human Beliefs and Values. A Cross-Cultural Sourcebook Based on the 1999-2002 Values Surveys. Mexico: Wydawnictwo Siglo Veintiuno, Siglo XXI. Argentyna.

Inglehart, R. (1977). The Silent Revolution: Changing Values and Political Systems among Western Publics. Princeton: Princeton University Press.

Jacob, M., Gerth, M., \& Weiss, F. (2018). Student employment: social differentials and fieldspecific developments in higher education. Journal of Education and Work, 31(1), 87108.

Klages, H. (2001). Brauchen wir eine Rçckkehr zu traditionellen Werten?. Aus Politik und Zeitgeschichte, 29, 7-14 
Kusy, Z., \& Zeman M. (2008) (Ed.). Vyskum Europskych Hodnot European Values Study 2008. Slovensko. Bratislava: Vydatelstvo IRIS.

Manuti, A., Curci, A., \& Van der Heijden, B. (2018). The meaning of working for young people: the case of the millennials. International Journal of Training and Development, 22(4), 274-288.

Mareš, P. (2004). Od práce emancipující k práci mizející. Sociologický časopis / Czech Sociological Review, 40(1), 37-48.

Marody, M. (2012). Dynamika postaw wobec pracy, in: A. Jasińska-Kania (Ed.). Wartości $i$ zmiany. Przemiany postaw Polaków $w$ jednoczacej się Europie, Warszawa: Wydawnictwo Naukowe „Scholar”, 63-77.

Mladek, J. (2012). Theory of Civilization Waves, Position and Future in Slovakia. American International Journal of Contemporary Research, 2(7), 230-241.

Novak V., \& Znidarsic, C. (2018). The Transition of Young People from Study to Employment in the Light of Student Work. Organizacija, 51(3), 195-206.

Siemieńska, R. (2004). Od wartości postmaterialistycznych do materialistycznych - casus Polski, in: M. Marody (Ed.). Zmiana czy stagnacja, Warszawa: Wydawnictwo „Scholar”, 177-206.

Sortheix, F.M., Parker, P.D., Lechner, C.M., \& Schwartz, S.H. (2019). Changes in Young Europeans' Values during the Global Financial Crisis. Social Psychological and Personality Science, 45, 15-25.

Standing, G. (2014). Prekariat. Nowa niebezpieczna klasa. Warszawa: PWN.

Standing, G. (2015). Karta prekariatu. Warszawa: Państwowe Wydawnictwo Naukowe.

Swadźba, U. (2001). Ślaski etos pracy. Studium socjologiczne. Katowice: Wydawnictwo Uniwersytetu Śląskiego.

Swadźba, U. (2012). From Materialistic to Post-Materialistic Values of Work? The Specifity of Poland, in: C. B. Illes (Ed.). Human Resource Management and Corporate Competitiveness. Godollo: Szent Istvan University Publishing House, 39-50.

Swadźba, U. (2013). Jak bliscy a jak różni. Analiza komparatystyczna wartości społeczeństwa polskiego i czeskiego, in: M. Dębiński, J. Makaro (Ed.) Sąsiedztwa III RP - Czechy. Zagadnienia społeczne. Wrocław: Wydawnictwo GAIT, 74-99.

Swadźba U. (2017). Theoretical and methodological problems of economic awareness analysis. In: I. Kosciarova, Z. Kadekova (Ed.). Managerial trends in the development of enterprises in globalization era. Online: http://spu.fem.uniag.sk/fem/ICoM_2017/files/international_scientific_conference_icom 2017.pdf $868-874$

Swadźba, U. (2018). Between professional work and student duties - values of work and its features in students`awareness, in: U. Swadźba (Ed.) The economic awareness of the young generation of Visegrad countries. A comparative analysis. Katowice: Wydawnictwo Uniwesytetu Śląskiego, 74-103.

Vlachová, K. (ed.) (2013). Česká republika 2002-2012: hodnoty, postoje, chování. Sociální report projektu European Social Survey. Praha: Sociologický ústav AV ČR.

Ziółkowski, M. (2006). Zmiany systemu wartości, in: W.J.Wasilewski (Ed.). Współczesne społeczeństwo polskie. Dynamika zmian. Warszawa: Wydawnictwo Naukowe Scholar, 145-174.

Zupan, N., Kase R., Yao K., \& Wang C.Y. (2015). Getting ready for the young generation to join the workforce: A comparative analysis of the work values of Chinese and Slovenian business students. Journal for East European Management Studies, 113, 174201. 


\section{Online documents:}

Boguszewski, R. (2015). Sytuacja zawodowa Polaków, Komunikat z badań CBOS (Public Opinion Reseach Center) (1475/2015). www.cbos.pl. Downloaded: 23.09.2017.

Hipsz, N. (2014). Polacy w pracy. Warunki zatrudnienia, gotowość do zmian, Komunikat z badań CBOS (Public Opinion Reseach Center) (132/2014). www.cbos.pl, Downloaded: 09.09.2017.

Kalka, J. (2016). Oceny sytuacji na rynku pracy i poczucie zagrożenia bezrobociem, Komunikat z badań CBOS (Public Opinion Reseach Center) (49/2016). www.cbos.pl. Downloaded: 09.09.2017.

Kowalczuk, K. (2014). O szansach młodych w III RP, Komunikat z badań CBOS (Public Opinion Reseach Center) (135/2014). www.cbos.pl. Downloaded: 25.09.2017. 